In cooperation with The Town of Ipswich, Massachusetts

\title{
Analysis of Mercury Wet-Deposition Data Collected with a Newly Designed Sampler, Boston, Massachusetts Metropolitan Area, 2002-04
}

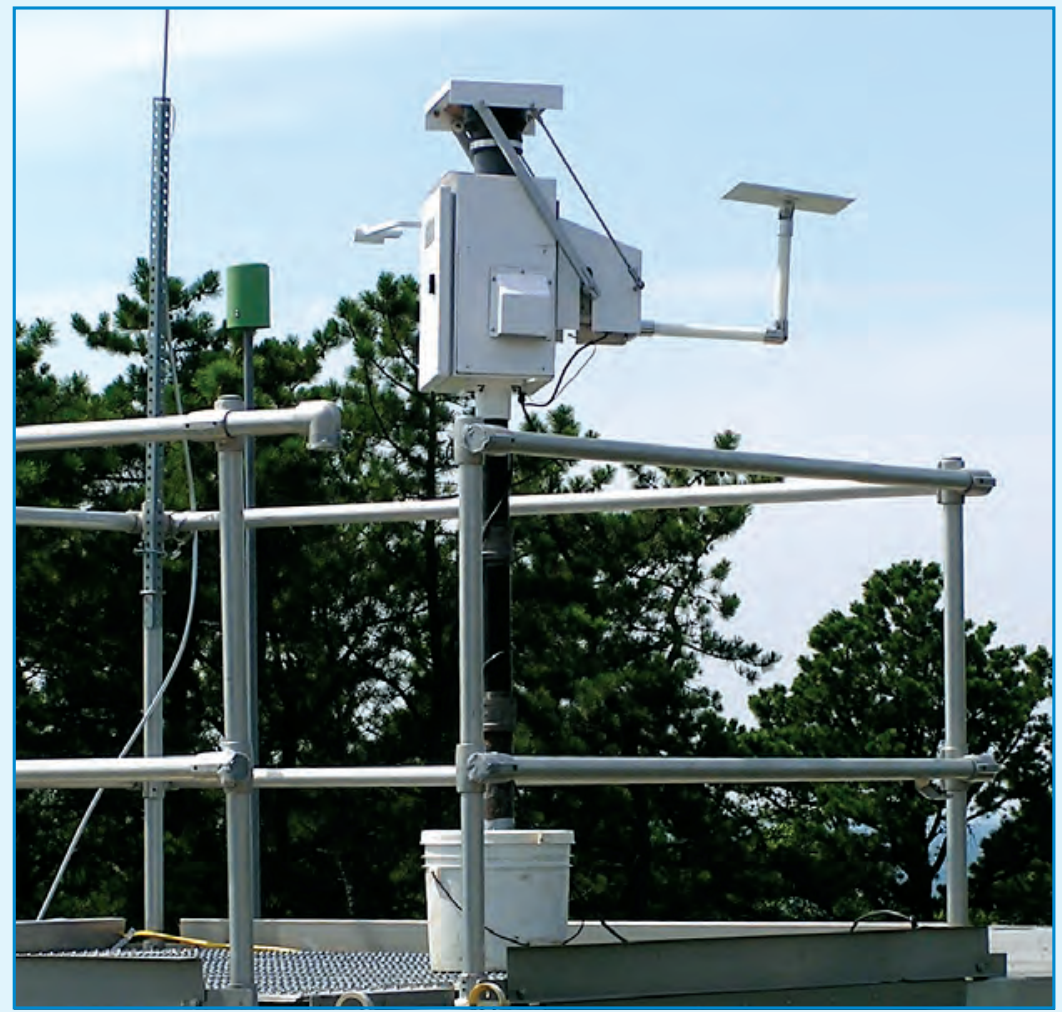

Open-File Report 2005-1368 
Cover. Photograph shows an N-Con sampler at Blue Hill Observatory, Milton, Mass. 


\section{Analysis of Mercury Wet-Deposition Data Collected with a Newly Designed Sampler, Boston, Massachusetts Metropolitan Area, 2002-04}

By Ann Chalmers, Mark A. Nilles, David P. Krabbenhoft, and Eric Prestbo

In cooperation with

The Town of Ipswich, Massachusetts

Open-File Report 2005-1368

U.S. Department of the Interior

U.S. Geological Survey 


\title{
U.S. Department of the Interior \\ Gale A. Norton, Secretary
}

\section{U.S. Geological Survey \\ P. Patrick Leahy, Acting Director}

\author{
U.S. Geological Survey, Reston, Virginia: 2005 \\ Revised: Version 1.01, 2005
}

For product and ordering information:

World Wide Web: http://www.usgs.gov/pubprod

Telephone: 1-888-ASK-USGS

For more information on the USGS - the Federal source for science about the Earth, its natural and living resources, natural hazards, and the environment:

World Wide Web: http://www.usgs.gov

Telephone: 1-888-ASK-USGS

Any use of trade, product, or firm names is for descriptive purposes only and does not imply endorsement by the U.S. Government.

Although this report is in the public domain, permission must be secured from the individual copyright owners to reproduce any copyrighted materials contained within this report.

Suggested citation:

Chalmers, Ann, Nilles, M.A., Krabbenhoft, D.P., and Prestbo, Eric, 2005, Analysis of mercury wet-deposition data collected with a newly designed sampler, Boston, Massachusetts Metropolitan Area, 2002-04: U.S. Geological Survey Open-File Report 2005-1368, 17 p. 


\section{Acknowledgments}

This study was done through the collaborative contributions of the U.S. Geological Survey (USGS) National Atmospheric Deposition Program, the USGS Mercury Research Laboratory in Middleton, Wis., Frontier Geosciences, New Hampshire Department of Environmental Services, Blue Hill Observatory, Eastern Region DOI Landscape Initiative, and the Ipswich EMPACT study. We thank the site operators, Leonard Raposa and Scott Klose, New Hampshire Department of Environmental Services; Don McCasland, Blue Hill Observatory; and Kimberly Campo, Sarah Flanagan, and Jeffrey Grey, USGS, for their outstanding work collecting samples and maintaining equipment. A special thanks to Jon Denner and Mark Olson, USGS, and Martha and Jack Beach, $\mathrm{N}$-CON Systems Co., Inc., for technical assistance throughout the study. Mark Brigham and John Coleman made many helpful contributions to the report. 



\section{Contents}





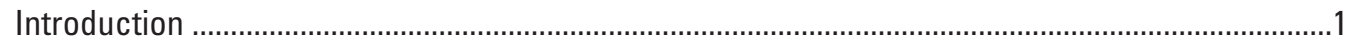

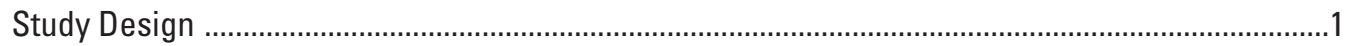

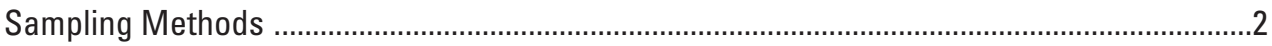

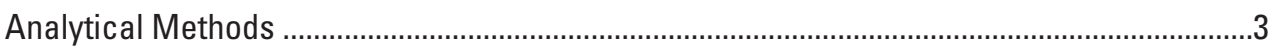

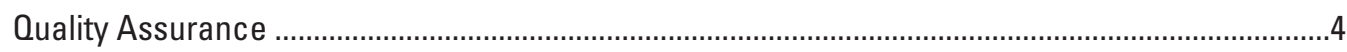

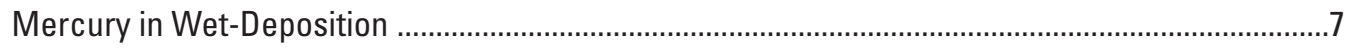

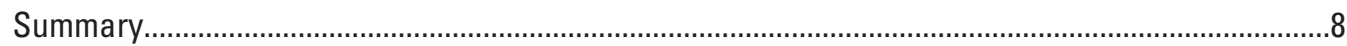

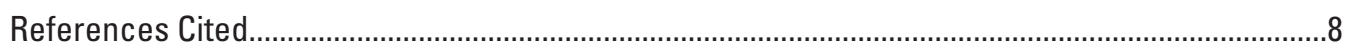

Appendix 1. Mercury wet-deposition data from Laconia, N.H. .................................................10

Appendix 2. Mercury wet-deposition data from Beverly Airport, Beverly, Mass. .........................13

Appendix 3. Mercury wet-deposition data from Manchester, N.H. ............................................14

Appendix 4. Mercury wet-deposition data from Blue Hill, Milton, Mass. ......................................16

Appendix 5. Sample collection protocol for the N-Con mercury sampler .....................................17

\section{Figures}

1. Map showing location of wet-deposition samplers around the Boston, Mass.

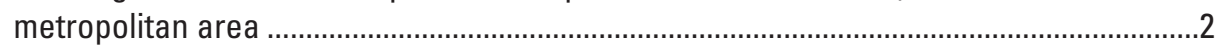

2. Photograph showing bottom-loading $\mathrm{N}$-Con mercury wet-deposition sampler, Manchester, Mass....................................................................................................

3. Photograph showing top-loading $\mathrm{N}$-Con mercury wet-deposition sampler, Blue Hill Observatory, Milton, Mass.................................................................................................

4. Graphs showing N-Con sampler lid openings compared to cumulative precipitation at Laconia, N.H., from May 1 to July 27, 2004..................................................................

\section{Tables}

1. Quality rating of samples from wet-deposition sites, Boston, Mass. metropolitan area ...........5

2. Summary statistics for total mercury concentration in precipitation and deposition at four sites around the Boston, Mass. metropolitan area, January 2002 to August 2004...........7 


\section{Conversion Factors and Water-Quality Units}

\begin{tabular}{|c|c|c|}
\hline Multiply & By & To obtain \\
\hline \multicolumn{3}{|c|}{ Length } \\
\hline foot $(\mathrm{ft})$ & 0.3048 & meter $(\mathrm{m})$ \\
\hline mile (mi) & 1.609 & kilometer $(\mathrm{km})$ \\
\hline
\end{tabular}

Temperature in degrees Celsius $\left({ }^{\circ} \mathrm{C}\right)$ may be converted to degrees Fahrenheit $\left({ }^{\circ} \mathrm{F}\right)$ as follows:

$$
{ }^{\circ} \mathrm{F}=\left(1.8 \times{ }^{\circ} \mathrm{C}\right)+32
$$

Concentrations of chemical constituents in water are given in nanogram per liter (ng/L). Mercury deposition is in nanogram per square meter $\left(\mathrm{ng} / \mathrm{m}^{2}\right)$, and rates of mercury deposition are in microgram per square meter per year $\left(\mu \mathrm{g} / \mathrm{m}^{2} / \mathrm{yr}\right)$. Volumes are in milliliters $(\mathrm{mL})$. Precipitation amounts are in millimeters (mm). 


\title{
Analysis of Mercury Wet-Deposition Data Collected with a Newly Designed Sampler, Boston, Massachusetts Metropolitan Area, 2002-04
}

\author{
By Ann Chalmers, Mark A. Nilles, David P. Krabbenhoft, and Eric Prestbo
}

\section{Abstract}

Atmospheric mercury wet-deposition rates were determined by the use of a newly designed wet-deposition sampler at four sites around the Boston, Mass. metropolitan area. The new sampler design was evaluated to determine reliability and capture efficiency. Capture efficiency was lowest during cold and (or) windy winter storms when accumulated ice and (or) snow either overflowed or blew out of the funnel. High capture efficiency (median values of 0.95 and 1.01) occurred with the top-loading type of $\mathrm{N}$-Con sampler, likely reflecting the enhanced collection efficiency of the optical infrared precipitation sensor during light precipitation, and the improved temperature distribution in the top-loading model. Wet-deposition samples collected from January 2002 to August 2004 were analyzed for total mercury ( $\mathrm{HgT}$ ), and a subset of samples from September 2003 to August 2004 were analyzed for methyl mercury (MeHg). MeHg concentrations at all four sites were below the detection level of 0.04 nanograms per liter (ng/L). Precipitation-weighted $\mathrm{HgT}$ concentrations during the study were 7.81 to $8.31 \mathrm{ng} / \mathrm{L}$ at the more urban sites, and $6.87 \mathrm{ng} / \mathrm{L}$ at the regional-reference site. Annual $\mathrm{HgT}$ deposition was 8.11 to 9.98 micrograms per square meter per year $\left(\mu \mathrm{g} / \mathrm{m}^{2} / \mathrm{yr}\right)$ at urban sites, and $6.56 \mu \mathrm{g} / \mathrm{m}^{2} / \mathrm{yr}$ at the regionalreference site. Precipitation-weighted $\mathrm{HgT}$ concentrations were 2 times higher in the summer than the winter, and the HgT deposition rate was 3 times higher in the spring and (or) summer than in the winter in the Boston metropolitan area.

\section{Introduction}

The rate of atmospheric mercury deposition predicted for New England from models is thought to be among the highest anywhere in the contiguous United States (U.S. Environmental Protection Agency, 1997; Seigneur and others, 2004), and is most likely the dominant source of mercury $(\mathrm{Hg})$ input to terrestrial and aquatic ecosystems. The origin of $\mathrm{Hg}$ deposited in ecosystems, however, is poorly understood. The relative contributions from global, national, regional, and local sources are highly variable across the country. In New England, more than half of the deposition is estimated to come from sources within the region (Northeast States for Coordinated Air Use Management, 1998), but previous sampling sites in New England lack the spatial resolution to detect regional changes in $\mathrm{Hg}$ deposition. The U.S. Geological Survey (USGS), in cooperation with the Town of Ipswich, Mass., and in collaboration with Frontier Geosciences, the New Hampshire Department of Environmental Services, and the Blue Hill Observatory, designed a four-site network to monitor $\mathrm{Hg}$ in wet deposition. The main goal of the monitoring network was to determine if there was any regional-scale variations in $\mathrm{Hg}$ wet-deposition around the Boston, Mass. metropolitan area (southeastern New Hampshire and eastern Massachusetts). Dry deposition is generally believed to represent as much as half of total mercury (HgT) deposition (Miller and others, 2005); however, quantifying dry deposition is beyond the scope of this study. This report describes reliability and collection efficiency of a newly designed wet-deposition sampler, and presents total $\mathrm{HgT}$ and methyl mercury $(\mathrm{MeHg}$ ) wet-deposition data and analysis from four sites around the Boston area.

\section{Study Design}

In 2002, four wet-deposition samplers were located along a 100-mi transect from central New Hampshire to southeastern Massachusetts (fig. 1). The three urban sites were in the Boston metropolitan area (Manchester, N.H., Beverly, Mass., and Blue Hill, Mass.), and the fourth (Laconia, N.H.) was in a rural area in central New Hampshire. The Laconia site served as a regional-reference site. The Laconia and Manchester sites are air-quality-monitoring sites for the New Hampshire Department of Environmental Services Air Resources Division. The Manchester site was in a parking lot in downtown Manchester, 60 mi north of Boston. Although this site was on the northern edge of the Boston metropolitan area, it had the most urban setting. The Beverly site was in a small airport in Beverly, Mass., 25 mi north of Boston. 


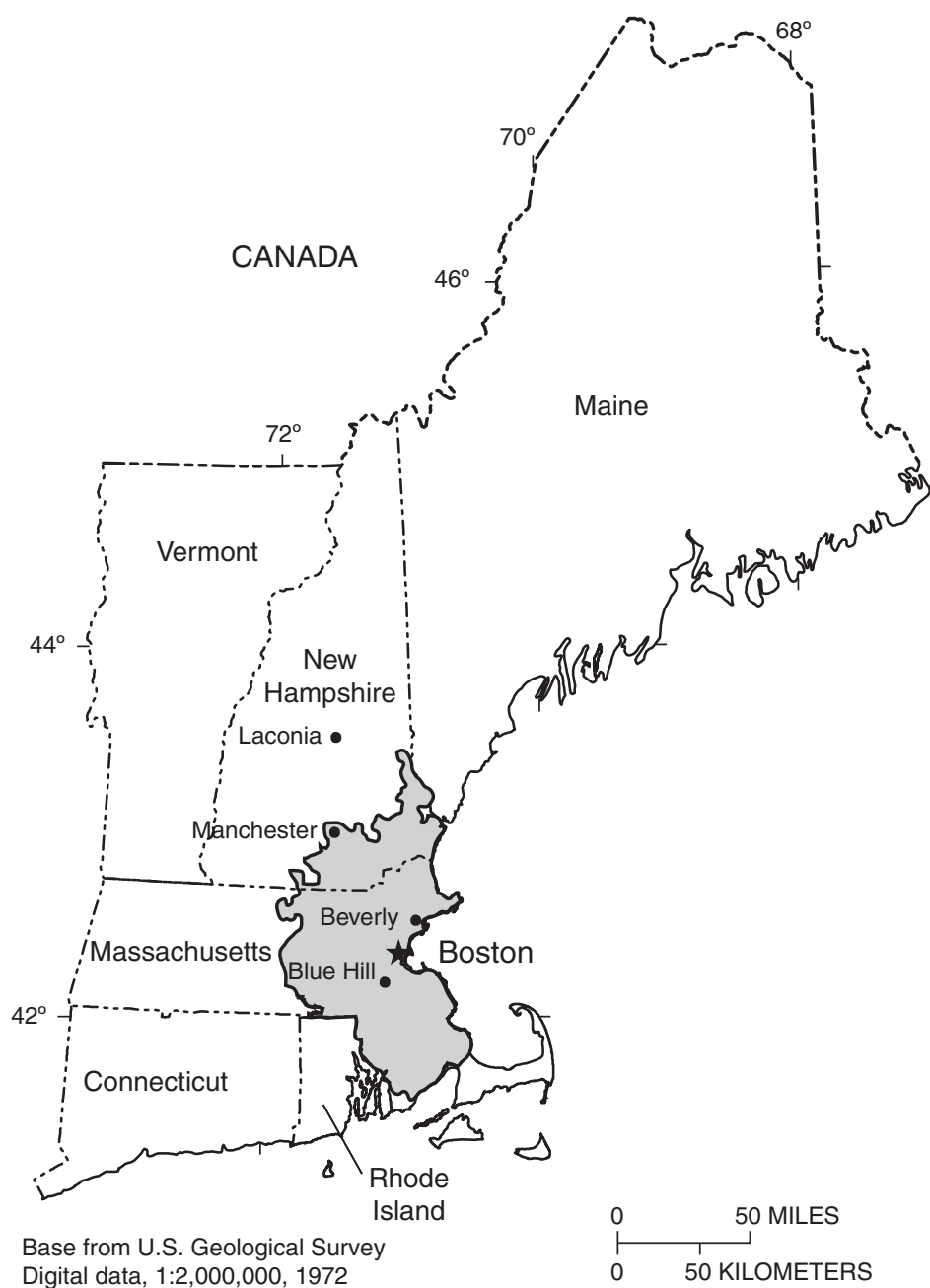

Figure 1. Location of wet-deposition samplers around the Boston, Mass. metropolitan area (in grey).

Beverly is a predominantly residential and commercial area, but is within 10-20 mi of several major sources of $\mathrm{Hg}$ emissions. The Blue Hill site was in Milton, Mass., at the Blue Hill Weather Observatory air-monitoring site for the Massachusetts Department of Environmental Protection. The site location, on top of Great Blue Hill just $10 \mathrm{mi}$ south of Boston, was removed from local urban effects such as street dust and automobile exhaust, but surrounded by long-range emissions sources from Providence, R.I., and New York City to the south, and Boston to the north.

The performance of a new mercury wet-deposition sampler (figs. 2 and 3) was evaluated to determine reliability and collection efficiency. The sampler was designed by N-Con Systems (Crawford, Ga.), per specifications of the National Atmospheric Deposition Program (NADP) Network Operation Subcommittee (National Atmospheric Deposition Program,
2005). The design included minimal horizontal surfaces to reduce contamination from splash, a powerful motor that eliminates problems related to icing and lids freezing during cold-weather sampling, and an optical infrared precipitation sensor to enhance collection efficiency during light precipitation. The infrared sensor opens the collector's lid when a designated number of particles above the size of fog are detected, and closes the lid within 2 minutes after the last drop has been detected. Funnel assemblies were designed by Eric Prestbo, Frontier Geosciences. Funnels were made of high-density polyethylene (HPDE), and tubing and fittings were fluorinated ethylene propylene (fluoropolymer FEP). Disposable radiation-sterilized polyethylene terephthalate copolyester (PETG) sampling bottles (Nalgene catalogue number 2019-2000) were used to eliminate cleaning costs. The funnel-bottle assemblies were tested to insure they meet chemical and storage criteria for mercury and trace-metal samples. Sampling and laboratory analytical methods used in this study are described in the following sections.

\section{Sampling Methods}

Samples were typically collected biweekly, but did vary from weekly (Laconia from January 2002 to December 2003) to an occasional monthly sample (Beverly and Blue Hill) over the period of the study (appendixes 1-4). A new PETG sample bottle and clean funnel assembly was used for every sample. Funnel assemblies were cleaned in $3.6 \mathrm{~N}$ hydrochloric acid $(\mathrm{HCl})$ bath for 24 hours, rinsed in double-deionized water, dried on a class-100 clean bench and stored in double zip-lock bags. Sampling bottles were precharged with $20 \mathrm{~mL}$ $0.12 \mathrm{~N} \mathrm{HCl}$ and weighed prior to installation in wetdeposition samplers. Samplers were inspected, cleaned, and samples collected following a modified version of the NADP Mercury Deposition Network protocols (appendix 5). Field blanks verified that decontamination procedures were adequate, and field and (or) laboratory procedures did not contaminate samples. Blank samples were collected by manually opening the sampler and pouring mercury-free water into a clean funnel-bottle assembly. Blanks were installed and removed from the sampler following the same procedure as was used for regular samples. Blank samples were collected four times a year.

Two different models of N-Con sampler were used in the study. For the first 1.5-2 years, a bottom-loading sampler was used where the bottle/funnel assembly was inserted up the sampler chimney and held in place against the lip of the chimney (fig. 2). The bottom-loading sampler was replaced with a top-loading sampler for the last $0.5-1$ year of the study. The top-loading sampler addressed concerns related to potential contamination from the chimney lip. The top-loading sampler was 
Figure 2. Bottom-loading $\mathrm{N}$-Con mercury wet-deposition sampler, Manchester, Mass.

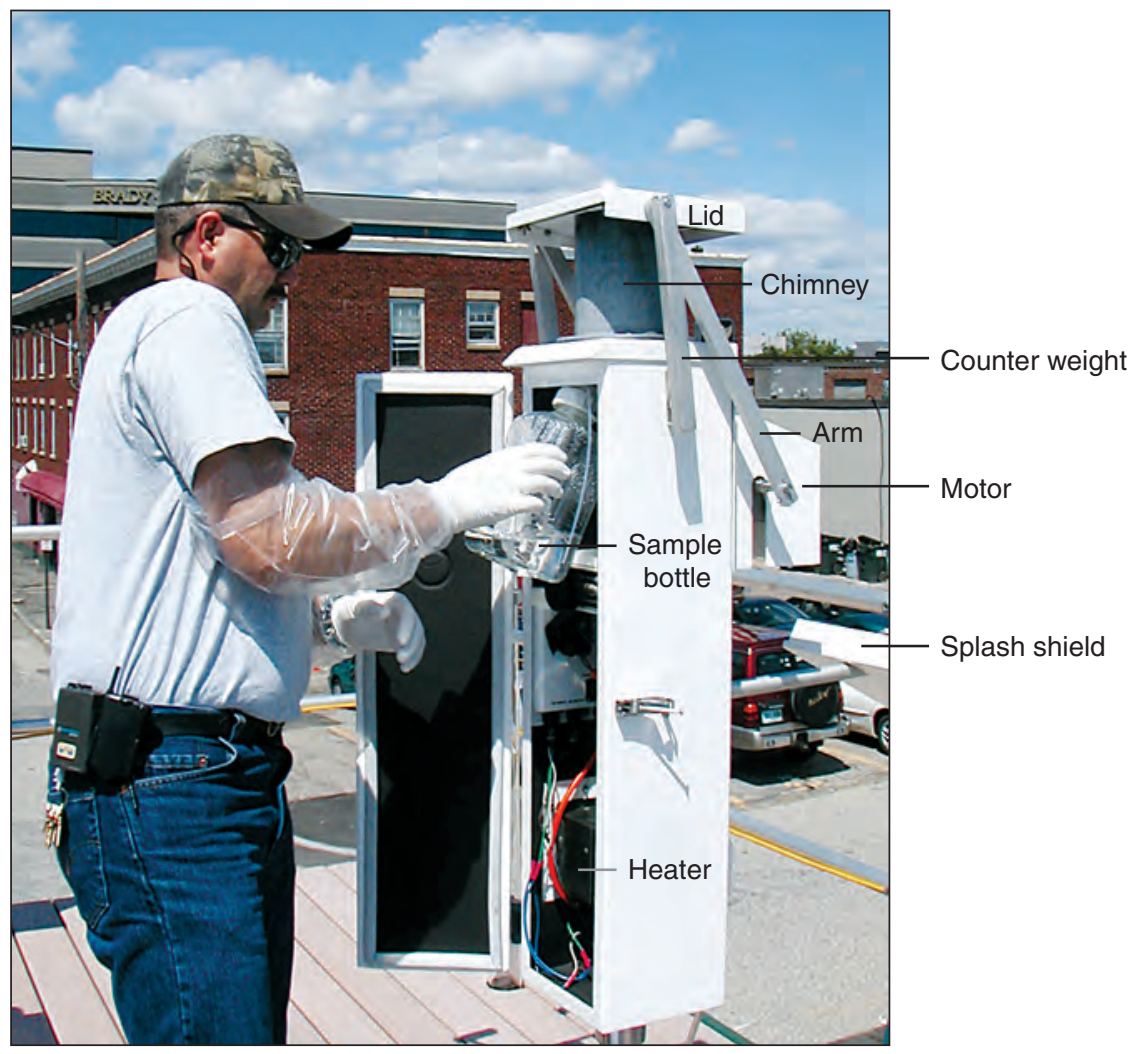

designed so the sample contacted only the laboratory-cleaned funnel assembly and PETG bottle. Control of the lid improved in the top-loading model with the use of four arms instead of two, and temperature control was improved by reducing the sampler size and internal volume, and placing a thermostatically controlled 300-watt silicone rubber plate heater next to the sample bottle (fig. 3). Wet-deposition collectors at Beverly and Blue Hill (fig. 1) were converted to the top-loading model on August 26 and 27, 2003, respectively; Laconia and Manchester sites were converted on April 20, 2004. To ensure the $\mathrm{Hg}$-deposition data were not affected by the different models of N-Con samplers, the same sensor, sample-collection train, and laboratory were used throughout the study; the height of sample collection was not changed; and blank samples were collected every 3 months throughout the study.

Wet-deposition sampling sites were located following siting criteria specified by National Atmospheric Deposition Program (2004b). Not all local siting criteria could be met at the more urban sites (Manchester and Blue Hill). For security, these sites had to be on top of trailers where recommended spacing between instruments (National Atmospheric Deposition Program, 2004b) could not be followed.

Precipitation data were collected from dedicated precipitation gages rather than from sample volumes. Three types of precipitation gages were used in this study. A Belfort rain gage was used at Laconia from January 2002 to December 2003.
Tipping-bucket rain gages were used at Manchester, Blue Hill, Beverly, and Laconia (January 2003 to July 2004). A standard National Weather Service tenite non-recording rain gage was used at the Manchester site for 6 months (July 2003 to January 2004). All rain gages were on site except the Manchester tipping bucket, which was at the Manchester Airport, $4.5 \mathrm{mi}$ from the site.

\section{Analytical Methods}

Mercury analysis was done by the USGS Mercury Research Laboratory in Middleton, Wis. HgT concentrations were determined by cold vapor atomic fluorescence spectroscopy (CVAFS) following oxidation with bromine monochloride $(\mathrm{BrCl})$ at $50^{\circ} \mathrm{C}$, reduction by stannous chloride $\left(\mathrm{SnCl}_{2}\right)$, and purge-and-trap of evolved zero-state mercury $\left(\mathrm{Hg}^{0}\right)$ onto gold-coated glass bead columns according to U.S. Environmental Protection Agency (USEPA) Method 1631 (USEPA, 2002; and Olson and DeWild, 1999). MeHg was analyzed with distillation and aqueous phase ethylation method and detection by CVAFS (DeWild and others, 2002). MeHg concentrations were analyzed from four seasonal volume-weighted composites taken from September to November 2003, December 2003 to February 2004, March to May 2004, and June to August 2004. Ten percent of the total sample volume was drawn off 


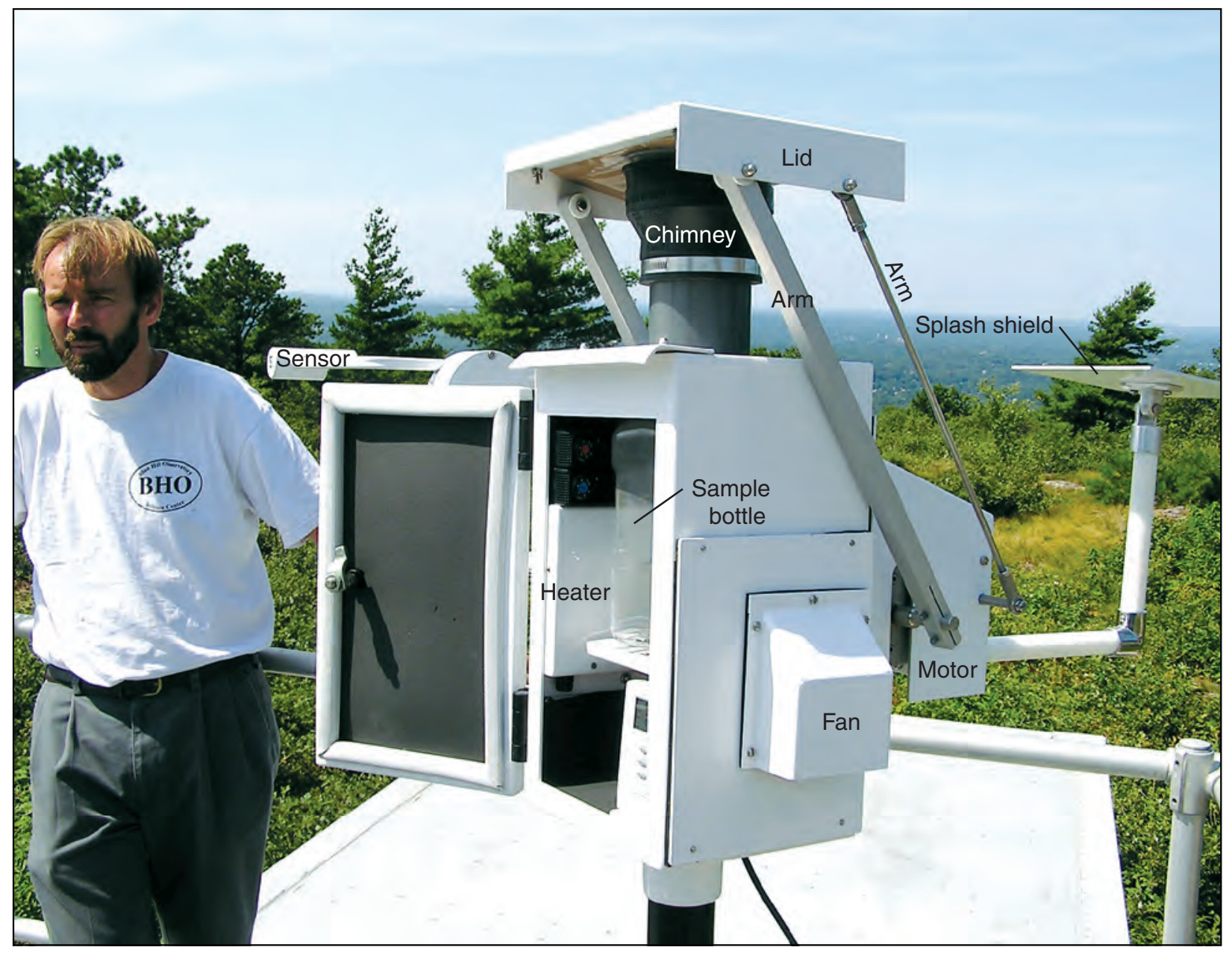

Figure 3. Top-loading N-Con mercury wet-deposition sampler, Blue Hill Observatory, Milton, Mass.

samples with sufficient volume ( $300 \mathrm{~mL}$ ) for $\mathrm{HgT}$ and $\mathrm{MeHg}$ analyses. Samples with less than $300 \mathrm{~mL}$ were analyzed for only HgT.

\section{Quality Assurance}

Blank samples were collected to monitor equipment cleaning and sample-handling techniques. The average $\mathrm{HgT}$ concentration in blank samples over the study period was $0.46 \pm 0.35 \mathrm{ng} / \mathrm{L}$, excluding one set of blank samples because of contamination of the associated source water. Average blank concentrations at sampling sites ranged from $0.34 \pm$ $0.14 \mathrm{ng} / \mathrm{L}$ at Blue Hills to $0.56 \pm 0.40 \mathrm{ng} / \mathrm{L}$ at Manchester. Bottom-loading samplers had lower $\mathrm{HgT}$ concentration in blank samples than top-loading samplers, suggesting contamination from the lip of the bottom-loading sampler was not a problem. HgT concentrations in blank samples collected from the bottom-loading sampler at Blue Hill and Beverly were $0.26 \pm 0.17 \mathrm{ng} / \mathrm{L}$ and $0.41 \pm 0.29 \mathrm{ng} / \mathrm{L}$, respectively, compared to $0.42 \pm 0.05 \mathrm{ng} / \mathrm{L}$ and $0.70 \pm 0.53 \mathrm{ng} / \mathrm{L}$, respectively, for the top-loading samplers at the same sites. $\mathrm{HgT}$ concentrations in blank samples from bottom-loading samplers at Laconia and Manchester were $0.35 \pm 0.39$ and $0.56 \pm 0.43 \mathrm{ng} / \mathrm{L}$, respectively, compared to 0.55 and $0.58 \mathrm{ng} / \mathrm{L}$ (one set of blanks), for top-loading samplers at these sites.

All sites except Beverly met the criteria for data completeness as specified by National Atmospheric Deposition Program (2004a). The criteria are based on the percentage of the study period for which there were valid data. The percentage of the valid data during this study ranged from 66 percent at Beverly Airport to 96 percent in Manchester (table 1). Beverly did not meet the criteria because of a period from December 2002 to June 2003 when the power supply 
Table 1. Quality rating of samples from wet-deposition sites, Boston, Mass. metropolitan area.

[Sampling sites shown on figure 1. 'A' rated samples that had no quality-assurance problems; 'B' rated samples had particulate matter or minor equipment problems; 'C' rated samples had bird feces, large insects, or major equipment problems during collection; 'C' rated samples were not valid samples]

\begin{tabular}{|c|c|c|c|c|}
\hline & Laconia, N.H. & Beverly, Mass. & Manchester, N.H. & Blue Hill, Milton, Mass. \\
\hline & \multicolumn{4}{|c|}{ Percent of study period with valid samples } \\
\hline & 95 & 66 & 96 & 91 \\
\hline & \multicolumn{4}{|c|}{ Quality rating of samples (percent) } \\
\hline A rating & 66 & 37 & 31 & 53 \\
\hline $\mathrm{B}$ rating & 29 & 49 & 68 & 41 \\
\hline \multirow[t]{2}{*}{$\mathrm{C}$ rating } & 5 & 13 & 1 & 6 \\
\hline & \multicolumn{4}{|c|}{ Type of quality-assurance problem (percent) } \\
\hline Plant matter & 6 & 15 & 27 & 13 \\
\hline Dust/dirt & 1 & 8 & 32 & 3 \\
\hline Insect matter & 12 & 8 & 2 & 8 \\
\hline Cloudy & 5 & 10 & 2 & 10 \\
\hline Bird feces & 4 & 13 & 0 & 5 \\
\hline Equipment failure & 9 & 40 & 21 & 23 \\
\hline $\begin{array}{l}\text { Temperature related } \\
\text { equipment failure }\end{array}$ & 7 & 13 & 5 & 15 \\
\hline
\end{tabular}

to the sampler was not working. Sample validity was defined according to the NADP quality-rating code (National Atmospheric Deposition Program, 2004c). Samples rated 'A' were valid samples with no quality-assurance problems. Samples rated 'B' were considered valid data with minor problems. Minor problems included particulate matter (dust and pollen), plant or insect matter in the sample, minor equipment failures such as false lid openings, and temperature-related problems such as ice and snow build-up in the funnel, or freezing temperatures inside the sample compartment. Samples rated ' $C$ ' were considered invalid data, and these data were not used in summary statistics. ' $C$ ' rated samples were compromised because of contamination from bird feces, large insects, or major equipment failure. Major equipment failures were related to either the heater or the lid not working properly on the bottom-loading samplers. Major equipment failures did not occur with the top-loading samplers. Most sample invalidations were caused by bird feces. The Beverly site had the most invalid samples (13 percent) followed by Blue Hill (6 percent), Laconia (5 percent), and Manchester (1 percent) (table 1). Most contamination from bird feces occurred in late spring and summer, at a time when $\mathrm{Hg}$ concentration in precipitation is typically highest. Because of the high percentage of invalid samples from bird feces at Beverly, the summary statistics may not accurately characterize this site. Particulate matter in the sample was the most common cause of minor problems with sample quality. Manchester had particulate matter in over half of the samples collected ( 55 percent), probably resulting from "street dust" at this highly urbanized site. The most common minor equipment problems were ice and snow build-up in the funnel, freezing temperatures inside the sample compartment, and false lid openings during dry periods. False openings resulted from blowing dust, snow, insects, or spider webs around the sensor. To document the approximate number of false openings, the amount of time the sampler lid was open from May 1, 2004, to July 27, 2004, was compared to periods of precipitation as indicated from the tipping-bucket rain gage at the Laconia site (fig. 4). Because of the capacity of the sensor to detect light rain that might not be enough to tip the rain gage, openings were only marked false if they occurred during clear or partly cloudy periods. During this 3-month period, the highest frequency of false openings occurred during June. The Laconia site operator confirmed that a spider web across the sensor in June was causing the sampler to open whenever the wind blew. The relatively long $(2+$ weeks $)$ sampling interval used in this study probably increased some of the most common quality-assurance problems by lengthening the time available for spiders to build webs in the sensors, and increasing the percentage of samples invalidated because of bird feces.

Capture efficiency of the wet-deposition samplers was calculated by comparing capture from the rain gage to that of the sampler (appendixes 1-4). Sample capture was the net sample-bottle catch divided by the catch area. Median capture efficiency ranged from 0.84 to 0.89 at the four sites. Capture efficiency was lowest during cold and (or) windy winter storms when accumulated ice and (or) snow in the funnel 

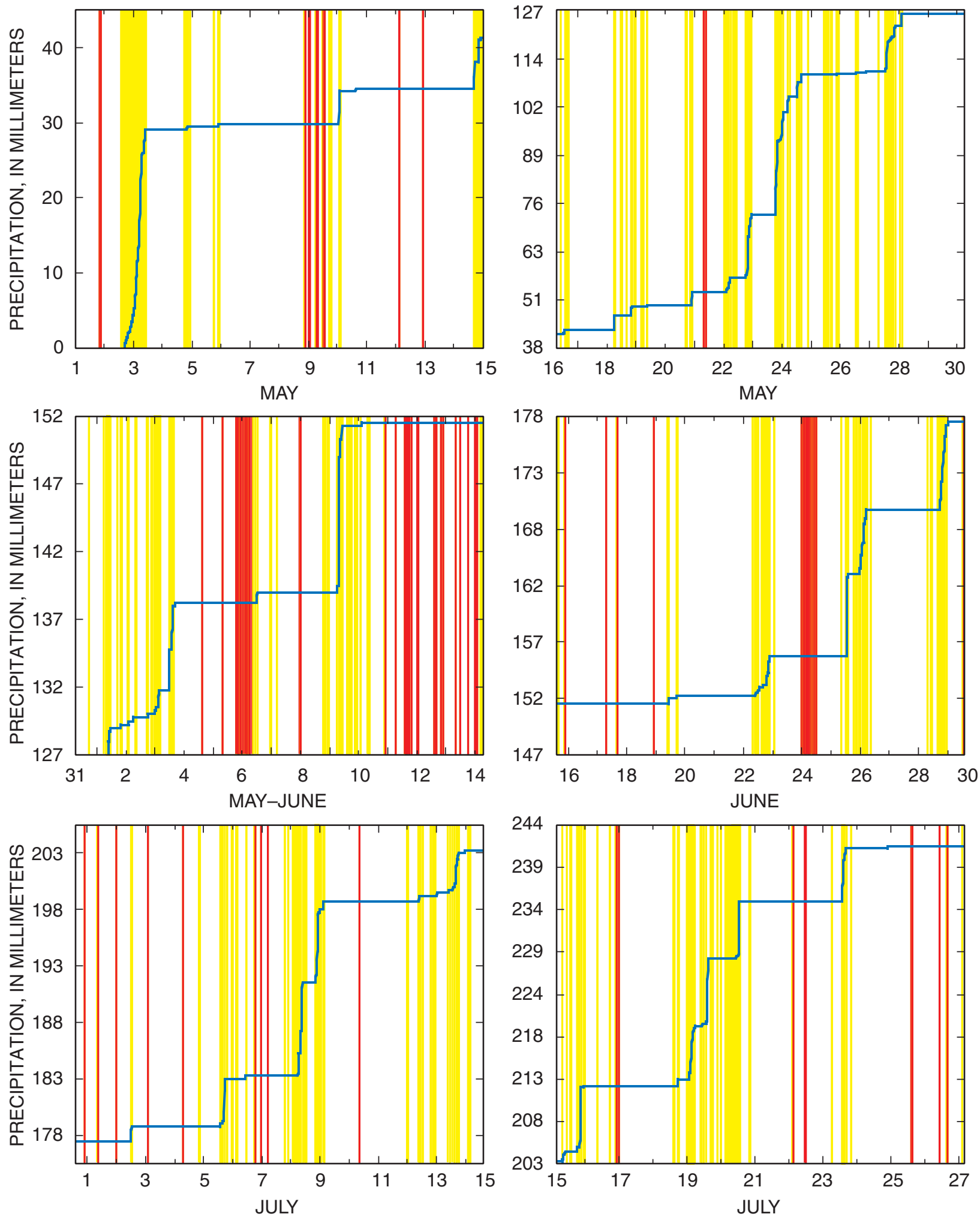

Figure 4. N-Con sampler lid openings compared to cumulative precipitation (blue line) at Laconia, N.H., from May 1 to July 27,2004 . Yellow highlights indicate times when the sampler lid was open during wet periods; red highlights are when the lid was open during dry periods. Lid was closed at all other times. 
either overflowed or blew out of the funnel. The highest capture efficiency occurred with the top-loading sampler, likely reflecting improved temperature distribution in the top-loading design. The median capture efficiency at Blue Hill increased from 0.79 (bottom-loading sampler used from January 2002 to August 2003) to 0.95 (top-loading sampler used from August 2003 to August 2004). During the same time period, median capture efficiencies at Beverly increased from 0.85 to 1.01 for bottom- and top-loading samplers, respectively. The lower capture efficiency with the original bottom-loading sampler design could also relate to leaky seals between the chimney lip and funnel caused by warping of the plastic funnels.

\section{Mercury in Wet-Deposition}

Concentrations of $\mathrm{HgT}$ in precipitation ranged from 0.73 to $24.6 \mathrm{ng} / \mathrm{L}$ at the four sites (table 2), whereas $\mathrm{MeHg}$ concentrations at all sites were below the detection level of 0.04 ng/L. The regional background site in Laconia, N.H., had the lowest HgT concentrations. Laconia had five samples collected during the study period (January 2002 to August 2004) with concentrations less than $2 \mathrm{ng} / \mathrm{L}$, compared to the urban sites, each only having one sample below $3 \mathrm{ng} / \mathrm{L}$ (appendixes 1-4). Concentrations of HgT were multiplied by the percent of precipitation that occurred during the sample period to obtain precipitation-weighted concentrations. HgT deposition is the product of the concentration of $\mathrm{HgT}$ in the sample and precipitation during that sample period; the annual HgT deposition rate is the sum of the $\mathrm{HgT}$ deposition divided by the number of years of the study. The regional background site in Laconia, N.H., had the lowest precipitation-weighted concentration, $6.87 \mathrm{ng} / \mathrm{L}$, and the lowest deposition rate, $6.56 \mu \mathrm{g} / \mathrm{m}^{2} / \mathrm{yr}$. The Manchester site, in the most urban environment, had the highest concentration sample (24.6 ng/L), the highest precipitation-weighted concentration $(8.31 \mathrm{ng} / \mathrm{L})$, and second highest deposition rate $\left(9.38 \mu \mathrm{g} / \mathrm{m}^{2} / \mathrm{yr}\right)$. Beverly Airport had a precipitation-weighted concentration of $8.16 \mathrm{ng} / \mathrm{L}$, and a deposition rate of $8.11 \mu \mathrm{g} / \mathrm{m}^{2} / \mathrm{yr}$. The Blue Hill site had a precipitationweighted concentration of $7.81 \mathrm{ng} / \mathrm{L}$, and the highest deposition rate $\left(9.98 \mu \mathrm{g} / \mathrm{m}^{2} / \mathrm{yr}\right)$. The average annual $\mathrm{Hg}$ wet-deposition rate at sites in metropolitan Boston (Manchester, Beverly, and Blue Hill) was $9.16 \mu \mathrm{g} / \mathrm{m}^{2}, 28$ percent higher than the $\mathrm{Hg}$ deposition rate at the regional background site. Seasonality was observed at all sites (table 2). Precipitation-weighted $\mathrm{HgT}$

Table 2. Summary statistics for total mercury concentration in precipitation and deposition at four sites around the Boston, Mass. metropolitan area, January 2002 to August 2004.

[HgT, total mercury; ng/L, nanograms per liter; $\mu \mathrm{g} / \mathrm{m}^{2} / \mathrm{yr}$, micrograms per meter squared per year]

\begin{tabular}{|c|c|c|c|c|}
\hline & Laconia, N.H. & Beverly, Mass. & Manchester, N.H. & Blue Hill, Milton, Mass. \\
\hline & \multicolumn{4}{|c|}{$\mathrm{HgT}$ concentration (ng/L) } \\
\hline Minimum & 0.73 & 2.87 & 2.63 & 2.47 \\
\hline \multirow[t]{2}{*}{ Maximum } & 23.70 & 22.60 & 24.60 & 23.40 \\
\hline & \multicolumn{4}{|c|}{ Median $\mathrm{HgT}$ concentration (ng/L) } \\
\hline Overall & 5.97 & 7.07 & 8.31 & 7.36 \\
\hline Spring & 6.14 & 6.83 & 8.45 & 8.03 \\
\hline Summer & 9.40 & 11.40 & 12.20 & 11.38 \\
\hline Fall & 4.97 & 5.68 & 5.99 & 5.69 \\
\hline \multirow[t]{2}{*}{ Winter } & 4.08 & 5.80 & 4.64 & 5.24 \\
\hline & \multicolumn{4}{|c|}{ Precipitation-weighted $\mathrm{HgT}$ concentration (ng/L) } \\
\hline Overall & 6.87 & 8.16 & 8.31 & 7.81 \\
\hline Spring & 7.40 & 6.98 & 8.58 & 9.50 \\
\hline Summer & 9.70 & 12.73 & 11.85 & 10.01 \\
\hline Fall & 5.13 & 5.28 & 5.45 & 5.52 \\
\hline \multirow[t]{2}{*}{ Winter } & 4.63 & 6.12 & 5.24 & 5.24 \\
\hline & \multicolumn{4}{|c|}{ HgT deposition $\left(\mu \mathrm{g} / \mathrm{m}^{2} / \mathrm{yr}\right)$} \\
\hline Overall & 6.56 & 8.11 & 9.38 & 9.98 \\
\hline Spring & 7.64 & 9.07 & 9.76 & 15.45 \\
\hline Summer & 7.75 & 10.20 & 13.48 & 9.03 \\
\hline Fall & 5.73 & 6.03 & 5.43 & 6.91 \\
\hline Winter & 2.62 & 3.56 & 4.17 & 5.03 \\
\hline
\end{tabular}


concentrations were 2 times higher in the summer than the winter. Because of increased precipitation during the spring and summer, the $\mathrm{HgT}$ deposition rate was 3 times higher in the spring or summer than in the winter.

\section{Summary}

The rate of atmospheric mercury $(\mathrm{Hg})$ deposition predicted for New England is thought to be among the highest anywhere in the contiguous United States and is most likely the dominant source of $\mathrm{Hg}$ input to terrestrial and aquatic ecosystems. In New England, more than half of the deposition is estimated to come from sources within the region. To determine if there are regional scale variations in $\mathrm{Hg}$ wet-deposition around the Boston, Mass. metropolitan area (southeastern New Hampshire and eastern Massachusetts), the U.S. Geological Survey, in cooperation with the Town of Ipswich, Mass., and in collaboration with Frontier Geosciences, the New Hampshire Department of Environmental Services, and the Blue Hill Observatory, designed a four-site network to monitor $\mathrm{Hg}$ in wet deposition.

Atmospheric $\mathrm{Hg}$ wet-deposition was examined by the use of newly designed wet-deposition sampler. The new sampler design was evaluated to determine reliability and capture efficiency. High capture efficiency (median values of 0.95 and 1.01) occurred with the top-loading sampler, likely reflecting the enhanced collection efficiency of the optical infrared precipitation sensor during light precipitation, and the improved temperature distribution in the top-loading model. Wet-deposition samples collected from January 2002 to August 2004 were analyzed for total mercury (HgT), and a subset of samples from September 2003 to August 2004 were analyzed for methyl mercury $(\mathrm{MeHg})$. Concentrations of $\mathrm{HgT}$ in precipitation ranged from 0.73 to $24.6 \mathrm{ng} / \mathrm{L}$ at the four sites, whereas $\mathrm{MeHg}$ concentrations at all sites were below the detection level of $0.04 \mathrm{ng} / \mathrm{L}$. The Manchester site, in the most urban environment, had the highest precipitation-weighted HgT concentration (8.31 ng/L), and Blue Hill, the closest site to Boston, had the highest deposition rate $\left(9.98 \mu \mathrm{g} / \mathrm{m}^{2} / \mathrm{yr}\right)$. The regional background site, in Laconia, N.H., had the lowest precipitation-weighted $\mathrm{HgT}$ concentration $(6.87 \mathrm{ng} / \mathrm{L})$ and the lowest deposition rate $\left(6.56 \mu \mathrm{g} / \mathrm{m}^{2} / \mathrm{yr}\right)$. The average annual $\mathrm{Hg}$ wet-deposition rate at sites in metropolitan Boston (Manchester, Beverly, and Blue Hill) was $9.16 \mu \mathrm{g} / \mathrm{m}^{2} ; 28$ percent higher than the $\mathrm{Hg}$ deposition rate at the regional background site.

\section{References Cited}

DeWild, J.F., Olson, M.L., and Olund, S.D., 2002, Determination of methyl mercury by aqueous phase ethylation, followed by gas chromatographic separation with cold vapor atomic fluorescence detection: U.S. Geological Survey Open-File Report 01-445, 14 p.

Miller, E.K., VanArsdale, Alan, Keeler, G.J., Chalmers, Ann, Poissant, Laurier, Kamman, N.C., and Brulotte, Raynald, 2005, Estimating and mapping of wet and dry mercury deposition across northeastern North America: Ecotoxicology, 14, p. 53-70.

National Atmospheric Deposition Program, 2004a, Description of parameters included in NADP/NTN report of wet-deposition data, accessed October 1, 2004, at http://nadp.sws.uiuc.edu/documentation/notes-depo.html

National Atmospheric Deposition Program, 2004b, Quality assurance support for the NADP, accessed October 7, 2004, at http://nadp.sws.uiuc.edu/QA/

National Atmospheric Deposition Program, 2004c, MDN data fields, accessed October 7, 2004, at http://nadp.sws.uiuc.edu/mdn/mdncodes 98. htm

National Atmospheric Deposition Program, 2005, Mercury Deposition Network Contact Information, accessed October 7, 2005, at http://nadp.sws.uiuc.edu/contacts.asp\#mdn

Northeast States for Coordinated Air Use Management, 1998, Northeast states and eastern Canadian provinces mercury study, A Framework for Action: Boston, Mass., 193 p. with appendixes.

Olson, M.L., and DeWild, J.F., 1999, Low-level techniques for the collection and species-specific analysis of low levels of mercury in water, sediment, and biota: U.S. Geological Survey Water-Resources Investigations Report 99-4018B, 11 p.

Seigneur, Christian, Vijayaraghavan, Krish, Lohman, Kristen, Karamchandani, Prakash, and Scott, Courtney, 2004, Global source attribution for mercury deposition in the United States: Environmental Science and Technology, v. 38, p. 555-569.

U.S. Environmental Protection Agency, 1997, Mercury study report to Congress Volume III: Fate and transport of mercury in the environment: Washington, D.C., Publication 452/R-97-005, section 5.

U.S. Environmental Protection Agency, 2002, Method 1631, revision E: mercury in water by oxidation, purge and trap, and cold vapor atomic fluorescence spectrometry: Washington D.C., EPA 821-R-02-019, 38 p. 


\section{Appendixes 1-5}


Table 1-1. Mercury wet-deposition data from Laconia, N.H.

[Date ON, mm/dd/yy sample collection started; Date OFF, mm/dd/yy sample collection ended; PPT, precipitation measured from rain gage; sample capture, sample volume divided by funnel area; mm, millimeters; HgT, total mercury; ng/L, nanograms per liter; DHgT, total mercury deposition; ng/m², nanograms per meter squared; na, not available; A, valid sample; B, valid sample with minor problems; C, invalid sample; c, contaminated sample; d, debris in sample; f, major equipment problem; m, missing data; $\mathrm{z}$, minor equipment problem; --, no quality-assurance problem]

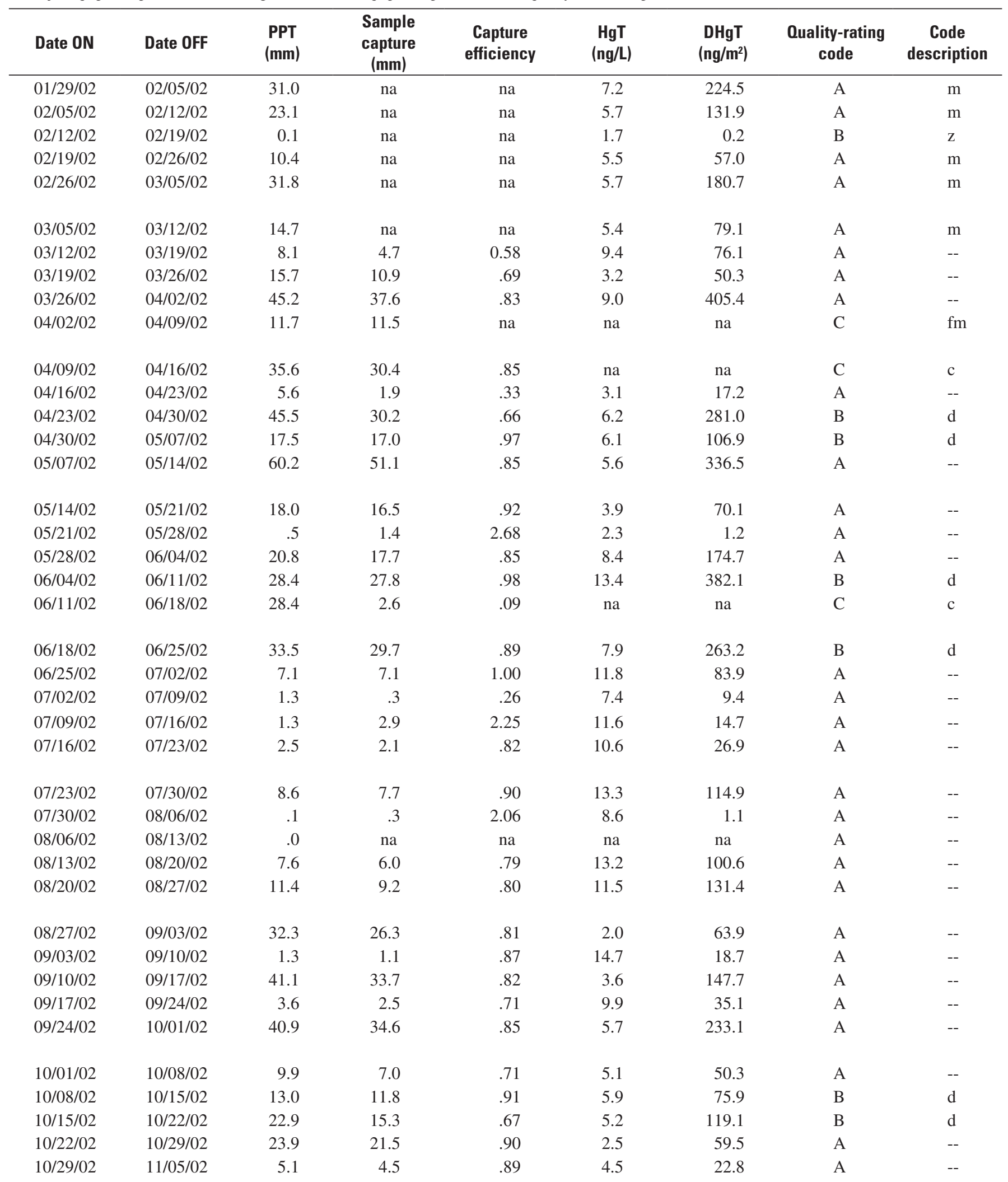


Table 1-1. Mercury wet-deposition data from Laconia, N.H.-Continued

[Date ON, mm/dd/yy sample collection started; Date OFF, mm/dd/yy sample collection ended; PPT, precipitation measured from rain gage; sample capture, sample volume divided by funnel area; mm, millimeters; HgT, total mercury; ng/L, nanograms per liter; DHgT, total mercury deposition; ng/m², nanograms per meter squared; na, not available; A, valid sample; B, valid sample with minor problems; C, invalid sample; c, contaminated sample; d, debris in sample; f, major equipment problem; m, missing data; z, minor equipment problem; --, no quality-assurance problem]

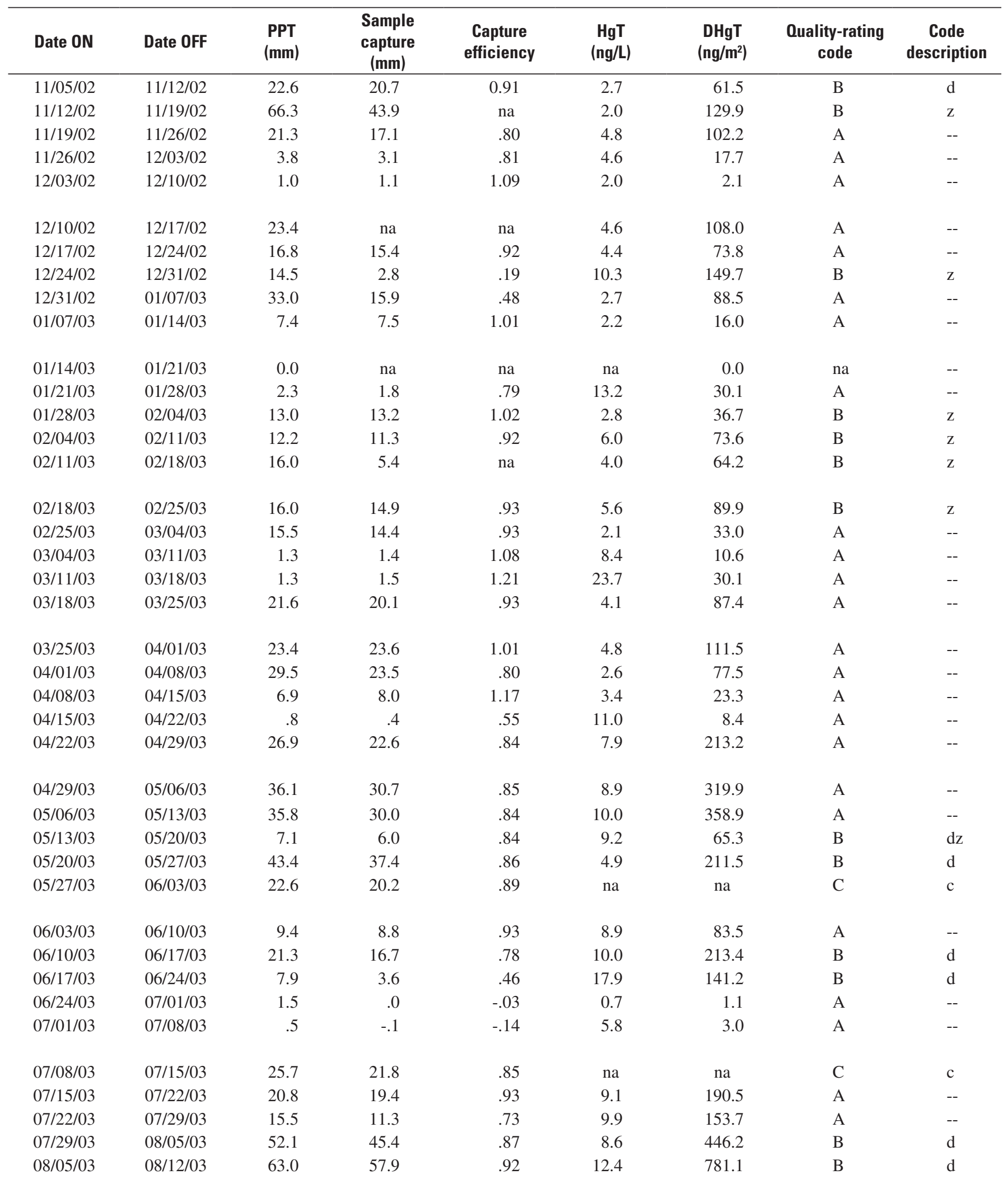


Table 1-1. Mercury wet-deposition data from Laconia, N.H.-Continued

[Date ON, mm/dd/yy sample collection started; Date OFF, mm/dd/yy sample collection ended; PPT, precipitation measured from rain gage; sample capture, sample volume divided by funnel area; mm, millimeters; HgT, total mercury; ng/L, nanograms per liter; DHgT, total mercury deposition; ng/m², nanograms per meter squared; na, not available; A, valid sample; B, valid sample with minor problems; C, invalid sample; c, contaminated sample; d, debris in sample; f, major equipment problem; m, missing data; $\mathrm{z}$, minor equipment problem; --, no quality-assurance problem]

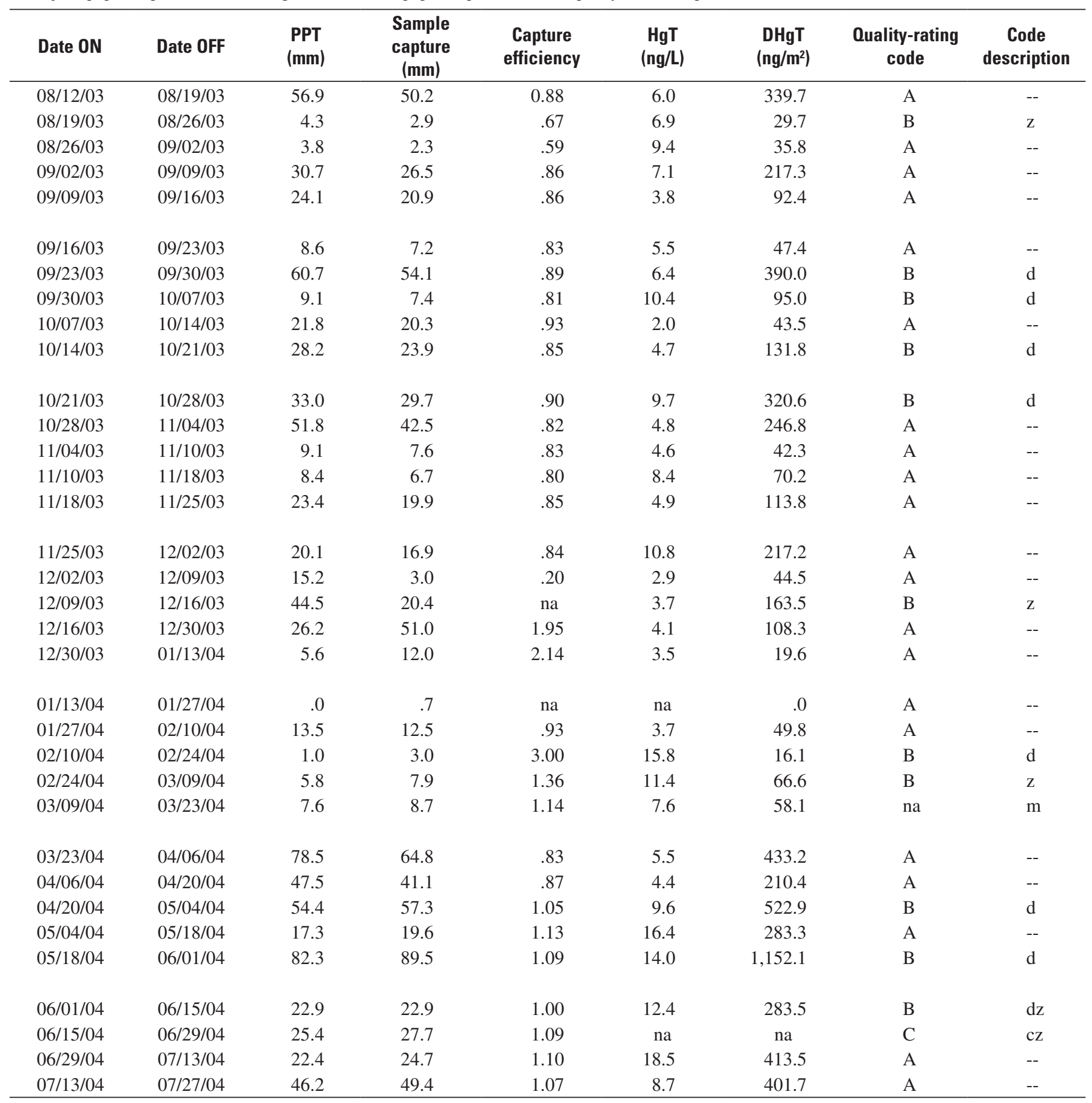


Table 2-1. Mercury wet-deposition data from Beverly Airport, Beverly, Mass.

[Date ON, mm/dd/yy sample collection started; Date OFF, mm/dd/yy sample collection ended; PPT, precipitation measured from rain gage; sample capture, sample volume divided by funnel area; mm, millimeters; HgT, total mercury; ng/L, nanograms per liter; DHgT, total mercury deposition; ng/m², nanograms per meter squared; na, not available; A, valid sample; B, valid sample with minor problems; C, invalid sample; c, contaminated sample; d, debris in sample; $\mathrm{f}$, major equipment problem; h, sample handling problem; m, missing data; $\mathrm{z}$, minor equipment problem; --, no quality-assurance problem]

\begin{tabular}{|c|c|c|c|c|c|c|c|c|}
\hline Date ON & Date OFF & $\begin{array}{c}\text { PPT } \\
(\mathrm{mm})\end{array}$ & $\begin{array}{c}\text { Sample } \\
\text { capture } \\
(\mathrm{mm})\end{array}$ & $\begin{array}{l}\text { Capture } \\
\text { efficiency }\end{array}$ & $\begin{array}{c}\mathrm{HgT} \\
\text { (ng/L) }\end{array}$ & $\begin{array}{c}\text { DHgT } \\
\left(\mathrm{ng} / \mathrm{m}^{2}\right)\end{array}$ & $\begin{array}{l}\text { Quality-rating } \\
\text { code }\end{array}$ & $\begin{array}{c}\text { Code } \\
\text { description }\end{array}$ \\
\hline $01 / 30 / 02$ & $02 / 12 / 02$ & 33.3 & na & na & 4.0 & 131.7 & B & $\mathrm{mz}$ \\
\hline $02 / 12 / 02$ & $02 / 26 / 02$ & 14.5 & na & na & 11.0 & 158.6 & B & $\mathrm{mz}$ \\
\hline 03/01/02 & $03 / 12 / 02$ & 22.9 & na & na & 5.7 & 129.5 & A & $\mathrm{m}$ \\
\hline 03/12/02 & $03 / 26 / 02$ & 38.9 & 37.2 & 0.96 & 5.7 & 222.8 & B & $\mathrm{z}$ \\
\hline 04/09/02 & $04 / 24 / 02$ & 11.7 & 10.5 & .90 & 11.6 & 135.8 & B & $\mathrm{z}$ \\
\hline $04 / 24 / 02$ & $05 / 10 / 02$ & 69.1 & 60.1 & na & na & na & $\mathrm{C}$ & $\mathrm{cm}$ \\
\hline 05/10/02 & $05 / 20 / 02$ & 108.7 & 89.5 & .82 & na & na & $\mathrm{C}$ & $\mathrm{c}$ \\
\hline 05/20/02 & $06 / 04 / 02$ & 19.1 & 16.7 & .88 & 18.8 & 357.4 & A & -- \\
\hline 06/04/02 & $06 / 18 / 02$ & 74.2 & 61.4 & .83 & 22.6 & $1,676.2$ & B & d \\
\hline 07/17/02 & $07 / 30 / 02$ & 23.9 & 19.5 & .82 & 14.6 & 348.6 & B & $\mathrm{z}$ \\
\hline 07/30/02 & 08/13/02 & 1.3 & na & na & na & na & $\mathrm{C}$ & $\mathrm{cm}$ \\
\hline 08/13/02 & $08 / 26 / 02$ & 23.9 & 19.8 & .83 & 8.4 & 199.6 & A & -- \\
\hline 08/26/02 & 09/09/02 & 44.5 & 38.6 & .87 & 4.6 & 204.5 & A & -- \\
\hline 09/09/02 & $09 / 24 / 02$ & 78.2 & 68.1 & .87 & 7.2 & 560.9 & A & -- \\
\hline 09/24/02 & $10 / 09 / 02$ & 19.6 & 17.2 & .88 & 4.9 & 95.8 & A & -- \\
\hline $10 / 09 / 02$ & $10 / 28 / 02$ & 100.8 & 84.0 & .83 & na & na & $\mathrm{C}$ & $\mathrm{c}$ \\
\hline $10 / 28 / 02$ & $11 / 19 / 02$ & 115.3 & 93.0 & .81 & 3.3 & 379.4 & B & $\mathrm{hz}$ \\
\hline $11 / 19 / 02$ & $12 / 18 / 02$ & 26.4 & 23.8 & na & 5.7 & 150.0 & B & $\mathrm{z}$ \\
\hline $10 / 18 / 03$ & $11 / 04 / 03$ & 63.0 & 66.4 & 1.05 & 7.1 & 445.6 & B & d \\
\hline $11 / 04 / 03$ & $11 / 18 / 03$ & 18.5 & 19.0 & 1.03 & 10.7 & 198.7 & A & -- \\
\hline $11 / 18 / 03$ & $01 / 08 / 04$ & 129.0 & 105.8 & .82 & 6.3 & 810.3 & B & $\mathrm{z}$ \\
\hline 01/08/04 & $02 / 06 / 04$ & 19.1 & -0.1 & -.01 & na & 0.0 & A & -- \\
\hline 02/06/04 & $02 / 24 / 04$ & 22.4 & 20.2 & .90 & 5.3 & 118.7 & A & -- \\
\hline $02 / 24 / 04$ & $03 / 11 / 04$ & 7.1 & 8.5 & 1.20 & 6.8 & 48.4 & A & -- \\
\hline 03/11/04 & $03 / 25 / 04$ & 25.9 & 16.4 & na & 6.7 & 174.4 & B & $\mathrm{z}$ \\
\hline $03 / 25 / 04$ & $04 / 06 / 04$ & 192.0 & 200.8 & na & 4.4 & 839.1 & B & $\mathrm{dz}$ \\
\hline 04/06/04 & $04 / 29 / 04$ & 96.0 & 98.5 & 1.03 & 9.7 & 927.5 & A & -- \\
\hline $04 / 29 / 04$ & $05 / 14 / 04$ & 23.9 & 24.3 & 1.02 & 6.9 & 163.6 & B & $\mathrm{d}$ \\
\hline 05/14/04 & 06/04/04 & 78.7 & 47.4 & na & na & na & $\mathrm{C}$ & $\mathrm{cz}$ \\
\hline 06/04/04 & $06 / 25 / 04$ & 30.0 & 30.3 & 1.01 & 12.0 & 359.7 & B & d \\
\hline $06 / 25 / 04$ & $07 / 16 / 04$ & 83.3 & 45.2 & na & 13.2 & $1,099.7$ & B & $\mathrm{dz}$ \\
\hline $07 / 16 / 04$ & $07 / 27 / 04$ & 26.9 & 77.6 & 2.88 & 2.9 & 77.3 & A & -- \\
\hline
\end{tabular}


Table 3-1. Mercury wet-deposition data from Manchester, N.H.

[Date ON, mm/dd/yy sample collection started; Date OFF, mm/dd/yy sample collection ended; PPT, precipitation measured from rain gage; sample capture, sample volume divided by funnel area; mm, millimeters; HgT, total mercury; ng/L, nanograms per liter; DHgT, total mercury deposition; ng/m², nanograms per meter squared; na, not available; A, valid sample; B, valid sample with minor problems; C, invalid sample; c, contaminated sample; d, debris in sample; f, major equipment problem; $\mathrm{m}$, missing data; $\mathrm{z}$, minor equipment problem; --, no quality-assurance problem]

\begin{tabular}{|c|c|c|c|c|c|c|c|c|}
\hline Date ON & Date OFF & $\begin{array}{l}\text { PPT } \\
(\mathrm{mm})\end{array}$ & $\begin{array}{c}\text { Sample } \\
\text { capture } \\
(\mathrm{mm})\end{array}$ & $\begin{array}{c}\text { Capture } \\
\text { efficiency }\end{array}$ & $\begin{array}{c}\mathrm{HgT} \\
\text { (ng/L) }\end{array}$ & $\begin{array}{c}\text { DHgT } \\
\left(\mathrm{ng} / \mathrm{m}^{2}\right)\end{array}$ & $\begin{array}{l}\text { Quality- } \\
\text { rating code }\end{array}$ & $\begin{array}{c}\text { Code } \\
\text { description }\end{array}$ \\
\hline $01 / 29 / 02$ & $02 / 12 / 02$ & 44.5 & na & na & 8.8 & 389.1 & $\mathrm{~A}$ & $\mathrm{~m}$ \\
\hline $02 / 19 / 02$ & $02 / 26 / 02$ & 8.9 & na & na & na & na & $\mathrm{C}$ & $\mathrm{fm}$ \\
\hline 02/26/02 & $03 / 12 / 02$ & 38.6 & na & na & 5.6 & 217.5 & A & $\mathrm{m}$ \\
\hline 03/12/02 & 03/26/02 & 31.5 & 24.2 & 0.77 & 6.3 & 198.2 & A & -- \\
\hline 03/26/02 & 04/09/02 & 66.0 & na & na & 9.7 & 639.4 & A & $\mathrm{m}$ \\
\hline 04/09/02 & $04 / 23 / 02$ & 18.0 & 15.5 & .86 & 11.0 & 197.8 & B & $\mathrm{dz}$ \\
\hline $04 / 23 / 02$ & $05 / 07 / 02$ & 55.9 & 45.7 & .82 & 7.4 & 414.6 & B & $\mathrm{z}$ \\
\hline 05/07/02 & $05 / 20 / 02$ & 83.8 & 69.3 & .83 & 9.2 & 768.6 & B & $\mathrm{dz}$ \\
\hline 06/04/02 & $06 / 18 / 02$ & 102.4 & 75.3 & .74 & 13.5 & $1,381.9$ & B & d \\
\hline 06/18/02 & $07 / 02 / 02$ & 152.4 & 26.3 & .17 & 8.8 & $1,339.6$ & B & $\mathrm{d}$ \\
\hline $07 / 02 / 02$ & 07/16/02 & 1.5 & na & na & 20.0 & 30.5 & B & $\mathrm{dm}$ \\
\hline 07/16/02 & $07 / 30 / 02$ & 14.5 & 18.6 & 1.29 & 10.7 & 154.9 & B & d \\
\hline 07/30/02 & 08/13/02 & 7.9 & 4.6 & .58 & 12.6 & 99.2 & A & -- \\
\hline 08/13/02 & 08/27/02 & 14.5 & 13.0 & .90 & 17.6 & 254.8 & B & d \\
\hline 08/27/02 & 09/10/02 & 30.2 & 29.3 & .97 & 7.5 & 227.9 & B & d \\
\hline 09/10/02 & $09 / 24 / 02$ & 30.7 & 31.7 & 1.03 & 11.0 & 338.1 & B & $\mathrm{d}$ \\
\hline 09/24/02 & $10 / 08 / 02$ & 28.2 & 28.7 & 1.02 & 9.1 & 256.3 & B & d \\
\hline $10 / 08 / 02$ & $10 / 22 / 02$ & 61.0 & 47.6 & .78 & 5.3 & 321.9 & B & $\mathrm{dz}$ \\
\hline $10 / 22 / 02$ & $11 / 05 / 02$ & 32.0 & 33.4 & 1.04 & 6.2 & 197.1 & A & -- \\
\hline $11 / 05 / 02$ & $11 / 19 / 02$ & 96.0 & 86.2 & .90 & 2.6 & 252.5 & A & -- \\
\hline $11 / 19 / 02$ & $12 / 03 / 02$ & 21.3 & 16.7 & na & 6.3 & 134.0 & B & $\mathrm{z}$ \\
\hline $12 / 03 / 02$ & $12 / 17 / 02$ & 56.9 & 43.6 & .77 & 7.8 & 440.9 & B & $\mathrm{dz}$ \\
\hline $12 / 17 / 02$ & $12 / 31 / 02$ & 46.0 & 25.8 & .56 & 3.4 & 155.9 & B & d \\
\hline $12 / 31 / 02$ & $01 / 14 / 03$ & 41.9 & 33.2 & .79 & 3.2 & 134.1 & B & $\mathrm{dz}$ \\
\hline 01/14/03 & $01 / 28 / 03$ & 1.8 & 1.1 & .64 & 17.2 & 30.5 & B & $\mathrm{d}$ \\
\hline $01 / 28 / 03$ & $02 / 11 / 03$ & 36.1 & 29.9 & .83 & 4.5 & 161.9 & B & z \\
\hline $02 / 11 / 03$ & $02 / 25 / 03$ & 65.5 & 36.9 & .56 & 5.3 & 349.3 & B & d \\
\hline $02 / 25 / 03$ & $03 / 11 / 03$ & 23.4 & 21.5 & .92 & 3.6 & 84.1 & A & -- \\
\hline 03/11/03 & $03 / 25 / 03$ & 24.1 & 21.7 & .90 & 7.8 & 187.7 & A & -- \\
\hline $03 / 25 / 03$ & 04/08/03 & 67.1 & 57.6 & .86 & 7.8 & 525.0 & B & $\mathrm{d}$ \\
\hline 04/08/03 & $04 / 22 / 03$ & 14.5 & 13.4 & .92 & 4.4 & 63.3 & A & -- \\
\hline $04 / 22 / 03$ & $05 / 06 / 03$ & 34.8 & 40.7 & 1.17 & 6.3 & 218.2 & A & -- \\
\hline 05/06/03 & $05 / 20 / 03$ & 34.5 & 22.9 & .66 & 11.8 & 407.6 & B & d \\
\hline 05/20/03 & 06/03/03 & 70.1 & 55.3 & .79 & 9.5 & 668.8 & B & d \\
\hline 06/03/03 & $06 / 17 / 03$ & 41.1 & 35.3 & .86 & 10.7 & 440.7 & B & d \\
\hline 06/17/03 & $07 / 01 / 03$ & 26.7 & 29.8 & 1.12 & 21.7 & 577.7 & B & d \\
\hline 07/01/03 & $07 / 15 / 03$ & 11.2 & 11.4 & 1.02 & 7.7 & 86.4 & B & d \\
\hline $07 / 15 / 03$ & $07 / 29 / 03$ & 21.3 & 21.8 & 1.02 & 12.2 & 260.3 & B & $\mathrm{d}$ \\
\hline $07 / 29 / 03$ & 08/04/03 & 169.7 & 148.0 & .87 & 9.9 & $1,676.4$ & A & -- \\
\hline
\end{tabular}


Table 3-1. Mercury wet-deposition data from Manchester, N.H.-Continued

[Date ON, mm/dd/yy sample collection started; Date OFF, $\mathrm{mm} / \mathrm{dd} / \mathrm{yy}$ sample collection ended; PPT, precipitation measured from rain gage; sample capture, sample volume divided by funnel area; mm, millimeters; $\mathrm{HgT}$, total mercury; $\mathrm{ng} / \mathrm{L}$, nanograms per liter; $\mathrm{DHgT}$, total mercury deposition; $\mathrm{ng} / \mathrm{m}^{2}$, nanograms per meter squared; na, not available; A, valid sample; B, valid sample with minor problems; C, invalid sample; c, contaminated sample; d, debris in sample; f, major equipment problem; m, missing data; $\mathrm{z}$, minor equipment problem; --, no quality-assurance problem]

\begin{tabular}{|c|c|c|c|c|c|c|c|c|}
\hline Date ON & Date OFF & $\begin{array}{l}\text { PPT } \\
(\mathrm{mm})\end{array}$ & $\begin{array}{c}\text { Sample } \\
\text { capture } \\
\text { (mm) }\end{array}$ & $\begin{array}{l}\text { Capture } \\
\text { efficiency }\end{array}$ & $\begin{array}{c}\mathrm{HgT} \\
\text { (ng/L) }\end{array}$ & $\begin{array}{c}\text { DHgT } \\
\left(\mathrm{ng} / \mathrm{m}^{2}\right)\end{array}$ & $\begin{array}{l}\text { Quality- } \\
\text { rating code }\end{array}$ & $\begin{array}{c}\text { Code } \\
\text { description }\end{array}$ \\
\hline $08 / 04 / 03$ & $08 / 12 / 03$ & 21.6 & 17.8 & 0.82 & 11.3 & 244.0 & A & -- \\
\hline 08/12/03 & 08/26/03 & 27.9 & 28.5 & 1.02 & 24.6 & 687.3 & B & $\mathrm{d}$ \\
\hline 08/26/03 & 09/09/03 & 25.4 & 23.3 & .92 & 5.8 & 147.6 & B & $\mathrm{d}$ \\
\hline 09/09/03 & 09/23/03 & 28.4 & 23.6 & .83 & 3.4 & 96.7 & A & -- \\
\hline 09/23/03 & $10 / 07 / 03$ & 78.0 & 69.5 & .89 & 4.1 & 321.3 & A & -- \\
\hline $10 / 07 / 03$ & $10 / 21 / 03$ & 42.2 & 35.4 & .84 & 4.7 & 198.8 & A & -- \\
\hline $10 / 21 / 03$ & $11 / 04 / 03$ & 72.1 & 61.4 & .85 & 5.2 & 375.9 & A & -- \\
\hline $11 / 04 / 03$ & $11 / 18 / 03$ & 13.0 & 12.1 & .93 & 6.4 & 83.0 & A & -- \\
\hline 11/18/03 & $12 / 02 / 03$ & 22.9 & 19.6 & .86 & 9.6 & 219.2 & B & $\mathrm{d}$ \\
\hline $12 / 02 / 03$ & $12 / 16 / 03$ & 57.2 & 27.2 & .48 & 4.3 & 246.9 & B & $\mathrm{dz}$ \\
\hline $12 / 16 / 03$ & $12 / 30 / 03$ & 39.6 & 16.8 & .42 & 3.4 & 133.1 & B & $\mathrm{d}$ \\
\hline 01/05/04 & $01 / 13 / 04$ & 4.8 & 5.1 & 1.05 & 4.4 & 21.0 & A & -- \\
\hline 01/13/04 & $01 / 27 / 04$ & .0 & 0.4 & na & na & 0.0 & A & -- \\
\hline 01/29/04 & $02 / 10 / 04$ & 26.2 & 23.8 & .91 & 4.8 & 125.1 & A & -- \\
\hline 02/10/04 & 02/24/04 & 1.8 & 1.8 & 1.00 & 13.4 & 23.8 & B & $\mathrm{d}$ \\
\hline $02 / 24 / 04$ & 03/09/04 & 9.7 & 6.7 & .69 & 9.2 & 88.5 & B & $\mathrm{z}$ \\
\hline 03/09/04 & $03 / 23 / 04$ & 17.3 & 14.5 & .84 & 9.1 & 156.7 & B & $\mathrm{d}$ \\
\hline 03/23/04 & $04 / 06 / 04$ & 130.3 & 102.8 & .79 & 3.6 & 469.1 & B & $\mathrm{d}$ \\
\hline 04/06/04 & $04 / 20 / 04$ & 48.3 & 46.2 & .96 & 6.1 & 292.5 & A & -- \\
\hline $04 / 20 / 04$ & 05/04/04 & 63.8 & 65.2 & 1.02 & 11.0 & 701.3 & A & -- \\
\hline 05/04/04 & 05/18/04 & 16.5 & 25.7 & 1.56 & 22.6 & 373.1 & B & $\mathrm{d}$ \\
\hline 05/18/04 & 06/01/04 & 99.6 & 94.3 & .95 & 14.7 & $1,463.6$ & B & $\mathrm{d}$ \\
\hline 06/01/04 & $06 / 15 / 04$ & 21.3 & 18.5 & .87 & 15.2 & 324.3 & A & -- \\
\hline 06/15/04 & 06/29/04 & 35.3 & 71.9 & 2.04 & 8.3 & 293.4 & B & $\mathrm{d}$ \\
\hline 06/29/04 & $07 / 13 / 04$ & 54.4 & 32.3 & .59 & 14.7 & 799.0 & B & $\mathrm{d}$ \\
\hline 07/13/04 & $07 / 27 / 04$ & 34.8 & 37.8 & 1.09 & 9.7 & 338.6 & $\mathrm{~B}$ & $\mathrm{~d}$ \\
\hline
\end{tabular}


Table 4-1. Mercury wet-deposition data from Blue Hill, Milton, Mass.

[Date ON, mm/dd/yy sample collection started; Date OFF, mm/dd/yy sample collection ended; PPT, precipitation measured from rain gage; sample capture, sample volume divided by funnel area; mm, millimeters; HgT, total mercury; ng/L, nanograms per liter; DHgT, total mercury deposition; ng/m², nanograms per meter squared; na, not available; A, valid sample; B, valid sample with minor problems; C, invalid sample; c, contaminated sample; d, debris in sample; f, major equipment problem; h, sample handling problem; m, missing data; $\mathrm{z}$, minor equipment problem; --, no quality-assurance problem]

\begin{tabular}{|c|c|c|c|c|c|c|c|c|}
\hline Date ON & Date OFF & $\begin{array}{l}\text { PPT } \\
(\mathrm{mm})\end{array}$ & $\begin{array}{c}\text { Sample } \\
\text { capture } \\
\text { (mm) }\end{array}$ & $\begin{array}{c}\text { Capture } \\
\text { efficiency }\end{array}$ & $\begin{array}{c}\mathrm{HgT} \\
\text { (ng/L) }\end{array}$ & $\begin{array}{c}\text { DHgT } \\
\left(\mathrm{ng} / \mathrm{m}^{2}\right)\end{array}$ & $\begin{array}{l}\text { Quality- } \\
\text { rating code }\end{array}$ & $\begin{array}{c}\text { Code } \\
\text { description }\end{array}$ \\
\hline na & $03 / 07 / 02$ & 9.2 & na & na & 7.7 & 70.6 & B & $\mathrm{zm}$ \\
\hline 03/19/02 & $03 / 27 / 02$ & 16.8 & na & na & 4.6 & 77.6 & A & $\mathrm{m}$ \\
\hline 04/02/02 & $04 / 17 / 02$ & 8.1 & na & na & 7.1 & 57.6 & A & $\mathrm{m}$ \\
\hline 04/17/02 & $04 / 24 / 02$ & 11.4 & 13.3 & 1.17 & 18.4 & 210.8 & A & -- \\
\hline 05/08/02 & $05 / 24 / 02$ & 108.5 & 93.9 & 0.87 & 15.2 & $1,648.6$ & B & $\mathrm{dz}$ \\
\hline 05/24/02 & 06/07/02 & 99.1 & 80.0 & na & 17.2 & $1,703.8$ & na & $\mathrm{m}$ \\
\hline 06/07/02 & $06 / 29 / 02$ & 53.3 & na & na & 14.1 & 752.1 & B & $\mathrm{d}$ \\
\hline 07/02/02 & $07 / 13 / 02$ & 18.8 & 15.4 & .82 & 9.3 & 174.8 & A & -- \\
\hline $10 / 25 / 02$ & $11 / 26 / 02$ & 192.3 & 149.7 & .78 & 4.0 & 774.9 & $\mathrm{~B}$ & $\mathrm{z}$ \\
\hline $11 / 26 / 02$ & $12 / 04 / 02$ & 17.8 & 3.1 & .18 & 3.4 & 59.7 & B & z \\
\hline $12 / 04 / 02$ & $12 / 18 / 02$ & 86.1 & 66.6 & na & 4.9 & 419.3 & B & $\mathrm{z}$ \\
\hline $12 / 18 / 02$ & $01 / 03 / 03$ & 87.6 & 39.9 & .46 & 4.8 & 418.9 & B & $\mathrm{z}$ \\
\hline 01/03/03 & $01 / 14 / 03$ & 45.2 & 37.3 & .82 & 2.5 & 111.7 & A & -- \\
\hline 01/14/03 & $02 / 03 / 03$ & 24.1 & 12.8 & .53 & na & na & A & $\mathrm{m}$ \\
\hline 02/03/03 & $02 / 17 / 03$ & 29.1 & 6.3 & .22 & 7.9 & 228.6 & na & $\mathrm{m}$ \\
\hline 02/17/03 & $02 / 27 / 03$ & 76.3 & 31.2 & .41 & 6.4 & 489.3 & A & -- \\
\hline 02/27/03 & $03 / 11 / 03$ & 40.6 & 21.6 & .53 & 4.0 & 161.7 & B & $\mathrm{h}$ \\
\hline 08/10/03 & 08/27/03 & 4.1 & 8.9 & 2.20 & 23.4 & 95.1 & B & $\mathrm{d}$ \\
\hline 08/27/03 & $09 / 15 / 03$ & 25.9 & 24.8 & .96 & 7.6 & 196.9 & A & -- \\
\hline 09/15/03 & $10 / 17 / 03$ & 99.6 & 93.2 & .94 & 4.4 & 436.6 & A & -- \\
\hline $10 / 17 / 03$ & $11 / 18 / 03$ & 78.2 & 102.9 & 1.32 & 8.2 & 639.1 & A & -- \\
\hline 11/18/03 & $12 / 12 / 03$ & 164.8 & 70.3 & .43 & 5.8 & 948.6 & A & -- \\
\hline $12 / 12 / 03$ & $01 / 17 / 04$ & 107.7 & 90.5 & .84 & 5.2 & 564.3 & A & -- \\
\hline 01/17/04 & $02 / 19 / 04$ & 48.5 & 33.8 & .70 & 4.6 & 222.2 & A & -- \\
\hline 02/19/04 & 03/09/04 & 20.6 & 12.4 & na & 7.2 & 148.1 & B & $\mathrm{zm}$ \\
\hline 03/09/04 & $04 / 08 / 04$ & 176.0 & 159.6 & .91 & 4.4 & 776.3 & A & -- \\
\hline 04/08/04 & 05/01/04 & 129.0 & 132.4 & 1.03 & 10.7 & $1,380.6$ & A & -- \\
\hline 05/01/04 & $05 / 24 / 04$ & 59.4 & 57.7 & .97 & 10.4 & 618.1 & B & $\mathrm{d}$ \\
\hline 05/24/04 & $06 / 21 / 04$ & 61.5 & 53.9 & .88 & 12.9 & 792.9 & B & $\mathrm{d}$ \\
\hline 07/06/04 & $07 / 23 / 04$ & 23.4 & 23.8 & 1.02 & 3.8 & 89.5 & A & -- \\
\hline 07/23/04 & 08/01/04 & 43.2 & 42.9 & .99 & 9.9 & 425.8 & $\mathrm{~B}$ & $\mathrm{~d}$ \\
\hline
\end{tabular}


Table 5-1. Sample collection protocol for the N-Con mercury sampler.

\section{CHECKING SAMPLER}

1. Approach the sampler on downwind side.

2. Wave hands in front of sensor until collector lid opens to check for correct sampler operation. Turn off (unplug) sampler when the lid is half open for cleaning and access to funnel.

3. Open sampler door.

4. Check maximum and minimum on the max-min thermometer. Maximum should not appreciably exceed outside ambient temperature since previous sampling visit. Minimum should be greater than $35^{\circ} \mathrm{F}$. Adjust thermostats if necessary. Reset max-min thermometer.

\section{REMOVING SAMPLE}

5. Put on pair of clean gloves.

6. Open zip-seal bags containing bottle cap.

7. Unscrew funnel/cap assembly.

8. Pull bottle out and down from sampler.

9. Cap "used" bottle, place capped bottle in its original sample zip-seal bag, seal, and write date and time off on outer bag.

10. Place "used” funnel/cap assembly in last week's zip-seal bag, seal and write date on outer bag.

\section{CLEANING SAMPLER}

11. Wipe underside of sampler lid with a mercury $(\mathrm{Hg})$-blank water moistened kim-wipe. Wipe both sensors and landing platform with kim-wipe (Hg-blank water not necessary).

12. Once a month also clean inside and below chimney and all horizontal surfaces on outside of monitor (Hg-blank water not necessary).

\section{INSTALLING CLEAN FUNNEL AND BOTTLE ASSEMBLY}

13. Put on a new pair of gloves.

14. Remove new funnel/cap assembly from zip-seal bags by holding either cap or neck of funnel (not top or inside funnel where sample will come in contact with funnel).

15. Place 1 gallon zip-seal bag over top of funnel, and a second (narrower) zip-seal bag over inflow tubing (overflow tubing does not need to be in a bag).

16. Grasp top of funnel with zip-seal bag and slowly place funnel cap assembly in chimney making sure zip-seal bag is protecting inflow tubing from touching sides of chimney.

17. Remove new bottle from bag, unscrew cap, and place cap back in original zip-seal bag.

18. Slowly and carefully remove zip-seal bag from inflow tubing and attach new sample bottle. Hold top of funnel with zip-seal bag and turn bottle to tighten cap.

19. Seal bags with bottle cap.

20. Turn on sampler and watch to make sure lid closes centered and snug on top of funnel.

21. Close sampler door.

\section{PAPERWORK}

22. Verify correct site name, date, and time are on outer zip-lock bag of sample bottle.

23. Wisconsin Mercury Research Lab Request for Analysis: fill in date, time, maximum and minimum temperatures, and sample condition (verify paperwork matches information on sample bottle).

Sample Condition - Identify and record any debris in sample or funnel and record sample condition. Choose from the following categories with additional descriptions in the comments section as needed:

Bird droppings

Cloudy or discolored

Soot/Ash/Dirt particles

Insects/Animal matter

Leaves/Twigs/Pollen/Plant matter

Other (please describe)

Comments - Please note any problems such as sampler malfunctioning, unusual conditions near site (construction, fire, and others), partial sample (include dates), leaking around funnel (for example, water in tray), ice in funnel, and others. 
Prepared by the New Hampshire-Vermont Water Science Center Publications Unit

For more information concerning the research in this report, contact:

Brian R. Mrazik, Director

U.S. Geological Survey

New Hampshire-Vermont Water Science Center

361 Commerce Way

Pembroke, NH 03275

or visit our Web site at:

http://nh.water.usgs.gov 


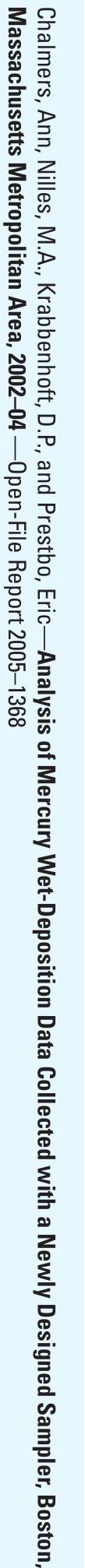

